\title{
Effects of Socialization Methods and Peer Attachment on Character Strength of School-Aged Children
}

\author{
Risa Umasyah* \\ Department of Family and Consumer Sciences, \\ Faculty of Human Ecology, \\ Bogor Agricultural University \\ Alfiasari
Department of Family and Consumer Sciences, \\ Faculty of Human Ecology, \\ Bogor Agricultural University \\ *Corresponding author: risaumasyah@gmail.com
}

\begin{abstract}
This study aimed to analyze the influences of socialization methods and peerattachment on character strength of scholl-aged in rural families. This study employed cross sectional approach using survey and interview. A hundred of families with children at grades 4 and 5 in two public elementary schools at Pamijahan Sub District, Bogor Regency participated in this study. This found only age and peer attachment that had significant influence on character strengths of school-aged children in rural families.
\end{abstract}

Keywords: character strength, peer attachment, school-age children, socialization methods, rural families

\begin{abstract}
Abstrak
Penelitian ini bertujuan untuk menganalisis pengaruh metode sosialisasi dan kelekatan teman sebaya terhadap kekuatan karakter anak usia sekolah pada keluarga perdesaan. Penelitian ini menggunakan desain cross sectional study dengan menggunakan metode survei dan wawancara Sebanyak 100 keluarga dengan responden ibu dan anak dipilih secara acak proporsional. Hasil menunjukkan bahwa hanya usia dan variabel kelekatan dengan teman sebaya yang berpengaruh nyata terhadap kekuatan karakter anak usia sekolah pada keluarga perdesaan.
\end{abstract}

Kata kunci: anak usia sekolah, kekuatan karakter, kelekatan teman sebaya, metode sosialisasi, keluarga perdesaan 


\section{Introduction}

Primary school-aged children are at a critical period. Therefore, children are expected to acquire knowledge considered essential for adapting toward the juvenile stage (Hurlock, 1980). In addition, at this time the child will experience an important stage in the formation of character and personality (Nadiya, 2013). According to Lickona (1994), school-aged children are at the stage of the third character namely interpersonal conformity. Previous research has found that the character strength shows a strong contribution to development of positive behavior and it is able to prevent the child from behavioral disorders (Park, 2004, as cited in Hastuti, Sarwoprasodjo, \& Alfiasari, 2013). There are six dimensions in character strength such as, the power of wisdom and knowledge, courage, humanity, justice, temperance and transcendence (Peterson \& Seligman, 2004).

Parents who live in rural areas should make a serious effort to be optimal in creating the character strength. To establish character strength, family do the socialization process of child character through socialization method. Socialization process of character is a process of how parents instill character values to their children. Socialization methods can be done through affection, operant, observation, cognition, socioculture, and appreticenchip (Berns, 1997). Previous research conducted by Pasaribu (2013) dealing with socialization method of parents in forming teenage characters, shows that the socialization method of mother positively affect teenage characters. Other studies also show that socialization has positive influence on the quality of the child character among youth (Alfiasari, Hastuti, \& Djamaluddin, 2013).

In addition to family, friend is also one of the agents of socialization. Hurlock (1980) explains that students of primary school are more influenced by their peers than their parents and other family members. The socialization process in friendship begins with the attachment (Marliani, 2014). Santrock (2007) emphasized that the closer relationship built infriendship, the higher its influence is. Peer attachment viewed from three dimensions: trust, communication, and alienation (Armsden \& Greenberg, 1987). This study aimed to: (1) analyze the characteristic of the child and family, socialization method, peer attachment, and character strength of school-aged children in rural families; (2) analyze the relationship between the characteristics of the child and family using socialization method, peer attachment, and character strength of school-aged children in rural families; and (3) analyze the influence of socialization and peer attachment methods towards character strength of school-aged children in rural families.

\section{Research Method}

\section{Participants}

Data were collected from 100 mothers and children grade 4 and 5 (10-13 years old) at Pamijahan Sub Districts. Participant in this research are mothers and children in rural families with income and educatiob low. 


\section{Measurements}

Socialization method used in this study was a questionnaire which refers to the concept of Berns (1997) and has been modified by Alfiasari, Hastuti, and Djamaluddin (2013). Initially, this socialization method has 42 statements. After internal validation, there are 39 valid statements with Cronbach's alpha value of 0,874 . The aspect in this instrument divided into six dimensions are Affective, Cognitive, Operant, Observation, Appreticenchip, and Sosioculture with a scale of 1 (almost never), 2 (sometimes), 3 (often) and 4 (always). The peer attachment questionnaire refers to concept of Armsden peers and Greenberg (1987) and has been modified by Naibaho (2013). Cronbach's alpha value of the peer attachment instrument was 0,790 and divided into three dimension such as Trust, communication, and acceptance.. this instrument has 20 valid statements with a scale of 1 (almost never), 2 (sometimes), 3 (often) and 4 (always). Instruments of character strength refers to the concept of Peterson and Seligman (2004) and has been modified by Alfiasari, Hastuti, and Djamaluddin (2013). Cronbach's alpha values of this instrument was 0,960 with 72 valid statements with a scale of 1 (not misrepresent the respondents), 2 (less misrepresent the respondents), and 3 (very misrepresent the respondents).

\section{Analysis}

The samples were selected randomly and proportionally. The data were processed through some steps such as editing, coding, data input, cleaning, and data analysis using Microsoft Office Excel and Statistical Package for Social Science (SPSS). The total score obtained is then transformed into an index score. The main variables in this study were categorizedusing a cut off system such as low $(<60)$, moderate (60-80), and high (>80). Data were analyzed descriptively (mean, standard deviation, minimum, and maximum score) and inferentially (correlation and linear regression).

\section{Result \\ Children and Family Characteristics \\ The results showed that child age ranged from 9-13 years old. About 50 percent of children were 11 years old. More than half $(55 \%)$ of the children were male and the rest $(45 \%)$ were female. The highest proportion paternal age is at middle age that is about 57 percent of the children with an average of 44,03 years old, while for the highest proportion of maternal age is at a young age that is about 62 percent of the children with an average of 38,19 years old. The average length of education done by father was 6,22 years, while the mother taking the average education was 5,79 years. These facts indicate that the level of mother education was lower than father education. Most families studied for less than 9 years. This indicates that the education in rural areas of Ciasmara and Ciasihanis is still low. In this study, most father worked as a labor and trader who migrated to the city, only about 22 percent of them who work as farmers, and most women only worked as a housewife. The average family income was Rp1.871.605 per month.}




\section{Socialization Method}

The research shows that the average achievement of socialization methods was 60,45 percent with a standard deviation of 10,95 . It means that socialization methods by mother has been done properly. The minimum score obtained by the method of socialization was 39 and the maximum score was 85. Among the six dimensions of socialization method, the highest achievement methodwas sosioculture with an average is 70,84. In addition, it can be seen from table 1 that operant method has lower achievement with an average of 52,66 in comparison to other socialization methods.

\section{Characteristics of Peer Group}

Characteristics of peer group was seen from the number of peer, age peer, and the length of friendship in the school environment, living environment, and other environments. Results showed that most children have a peer group which consisted of 1-3 people, in the school environment, living environment, and other environment. More than half peer were in the same age in the school environment $(57 \%)$ and more than 60 percent were in different age in neighborhood and other neighborhoods. In the school environment, living environment and other environments, most children have already had friendship for more than 12 months.

\section{Peer Attachment}

Research results showed that the achievements of peer attachment has an average of 66,78 with a standard deviation of 15,89 . Achievement of peer attachment dimension such as trust dimensions was 70,35 as the highest average, and next is the acceptance dimension has an average of 66,58 and the average of communication dimension was 63,26.

\section{Character Strength of School Age Children}

Table 1 shows that the character strength of school-age children has high achievement with average of 87,30 and a standard deviation of 7,76. Among the six dimensions of character strength, the highest achievement character strength was transcendence with an average of 90,89 with a standard deviation of 7,56.

Table 1 The value of minimum, maximum, mean, and standard deviation index score of character strength

\begin{tabular}{lccccc}
\hline \multicolumn{1}{c}{ Dimension } & Minimum & Maximum & Mean & \pm & SD \\
\hline Wisdom & 50,00 & 100,00 & 84,83 & \pm & 13,63 \\
Courage & 44,00 & 100,00 & 85,73 & \pm & 13,44 \\
Humanity & 50,00 & 96,00 & 88,94 & \pm & 10,22 \\
Justice & 53,00 & 100,00 & 84,71 & \pm & 11,15 \\
Temperance & 41,00 & 100,00 & 88,21 & \pm & 11,20 \\
Transcendence & 60,00 & 100,00 & 90,89 & \pm & 7,56 \\
Total & 56,00 & 98,00 & 87,30 & \pm & 7,76 \\
\hline
\end{tabular}




\section{Relationship between Children and Family Characteristics with Some Factors of Socialization Method}

The results of relationship test between the child and family characteristics with socialization method showed that family income per capita had a significantly positive relationship with the dimension of operant method and socialization method as a whole. It means that the greater the family income was, the better the way of mothers do operant and socialization method will be.

Table 2 Corelation coefficient between child and family characteristics with some factors of socialization method

\begin{tabular}{|c|c|c|c|c|c|c|c|}
\hline \multirow{2}{*}{ Variable } & \multicolumn{6}{|c|}{ Socialization method } & \multirow{2}{*}{ Total } \\
\hline & Afec & $\operatorname{Cog}$ & Oper & Obser & Apre & Sosio & \\
\hline \multicolumn{8}{|c|}{ Child characteristic } \\
\hline Age & $-0,196$ & $-0,162$ & $-0,105$ & $-0,067$ & $-0,123$ & $-0,136$ & $-0,185$ \\
\hline Sex & 0,115 & 0,704 & 0,617 & 0,662 & 0,517 & 0,100 & 0,388 \\
\hline \multicolumn{8}{|c|}{ Family characteristic } \\
\hline Age of father & 0,020 & $-0,085$ & $-0,069$ & 0,076 & 0,063 & $-0,034$ & $-0,018$ \\
\hline Age of mother & $-0,001$ & $-0,142$ & $-0,039$ & 0,084 & 0,049 & $-0,071$ & $-0,036$ \\
\hline $\begin{array}{l}\text { Length of study } \\
\text { of father }\end{array}$ & $-0,139$ & 0,001 & 0,011 & $-0,106$ & $-0,004$ & 0,000 & $-0,029$ \\
\hline $\begin{array}{l}\text { Length of study } \\
\text { of mother }\end{array}$ & 0,047 & 0,121 & 0,105 & 0,159 & 0,089 & 0,141 & 0,149 \\
\hline $\begin{array}{l}\text { Income } \\
\text { capita }\end{array}$ & 0,163 & $-0,096$ & $0,217^{*}$ & 0,119 & 0,120 & 0,075 & 0,142 \\
\hline Family size & $-0,009$ & $-0,021$ & 0,046 & 0,064 & 0,156 & 0,023 & 0,070 \\
\hline
\end{tabular}

Afec: Afective; Oper: Operan; Obs: Observation; Cog: Cognitive; Appre:Appreticenchip;Sos: Socioculture

\section{Relationship between Children and Family Characteristics with Peer Attachment}

Table 3 shows that there was a relationship of the age of child, age of mother, length of study of father, and family size with peer attachment dimension. The table below shows the correlation between the characteristic of children and families with peer attachment.

Table 3 Corelation coefficient between child and family characteristics with peer attachment

\begin{tabular}{lcccr}
\hline \multirow{2}{*}{ Variable } & \multicolumn{3}{c}{ Peer Attachment } & \multirow{2}{*}{ Total } \\
\cline { 2 - 4 } \cline { 2 - 3 } Child characteristic & Trust & Communication & Acceptance & \\
Age & 0,095 & $-0,119$ & $0,255^{*}$ & 0,042 \\
Sex & 0,760 & 0,467 & $-0,032$ & $-0,067$ \\
Family characteristic & & & & \\
Age of father & 0,024 & $-0,097$ & 0,143 & 0,037 \\
Age of mother & 0,103 & 0,010 & $0,212^{*}$ & 0,156 \\
Length of study of father & 0,149 & $0,193^{*}$ & 0,028 & 0,193 \\
Length of study of mother & $-0,027$ & 0,068 & $-0,103$ & $-0,048$ \\
Income per capita & $-0,134$ & $-0,105$ & $-0,011$ & $-0,164$ \\
Family size & $0,166^{*}$ & 0,037 & 0,177 & 0,174 \\
\hline
\end{tabular}


$(* *)$ significant at $\mathrm{p}<0,01 ;(*)$ significant at $\mathrm{p}<0,05$

The result showed that age of child and age of mother had a significantly positive relationship with acceptance dimension. Length of study of father had a significantly positive relationship with communication dimension. Then, family size had a significantly positive relationship with trust dimension.

\section{The Relationship Between Child Characteristics, Family Characteristics, Socialization Method, Peer Attachment, and Character Strength}

Table 4 shows the results of relationship between the characteristics of child and family, socialization method and peer attachment with character strength. Based on the table, length study of father is positively related with courage, transcendence, and total of character dimension. It means that the longer the education of father was, the better character of courage, transcendence, and total of overall character were. The length of education of mother was significantly positive related to the character of courage. It means that the longer the education of mother was, the better the character of courage was. Peer attachent was positively related to the dimension of courage, humanity, justice and transcendence and total of overall character were dimension.

Table 4 Corelation coefficient between child characteristics, family characteristics, socialization method, and peer attachment with character strength of school aged children

\begin{tabular}{|c|c|c|c|c|c|c|c|}
\hline \multirow{2}{*}{ Variable } & \multicolumn{6}{|c|}{ Character Strength } & \multirow{2}{*}{ Total } \\
\hline & 1 & 2 & 3 & 4 & 5 & 6 & \\
\hline \multicolumn{8}{|l|}{ Child characteristic } \\
\hline Age & 0,096 & 0,073 & 0,066 & 0,073 & 0,049 & 0,082 & 0,108 \\
\hline Sex & 0,001 & $-0,102$ & $-0,158$ & $-0,049$ & $-0,091$ & $-0,117$ & $-0,111$ \\
\hline \multicolumn{8}{|l|}{ Family characteristic } \\
\hline Age of father & $-0,048$ & $-0,039$ & 0,027 & $-0,056$ & 0,151 & 0,038 & 0,017 \\
\hline Age of mother & $-0,049$ & $-0,039$ & $-0,024$ & $-0,050$ & 0,127 & 0,012 & $-0,002$ \\
\hline Length of study of father & 0,125 & $0,210 *$ & 0,128 & 0,170 & 0,128 & $0,223 *$ & $0,234 *$ \\
\hline Length of study of mother & 0,149 & $0,247 *$ & 0,087 & 0,089 & 0,099 & 0,134 & 0,181 \\
\hline Income per capita & 0,108 & $-0,128$ & $-0,108$ & 0,062 & 0,006 & 0,125 & 0,011 \\
\hline Family size & 0,006 & 0,023 & 0,013 & 0,084 & 0,053 & $-0,024$ & 0,052 \\
\hline Socialization method & $-0,046$ & 0,022 & 0,011 & 0,144 & 0,052 & $-0,141$ & 0,018 \\
\hline Peer attachment & 0,168 & $0 ., 326 * *$ & $0,376 * *$ & $0,247 *$ & $0,297 * *$ & $0,237 *$ & $0,383 *$ \\
\hline
\end{tabular}

1. Wisdom; 2. Courage; 3. Humanity; 4. Justice; 5. Temperance; 6 . Trancendence

$(* *)$ significant at $\mathrm{p}<0,01 ;(*)$ significant at $\mathrm{p}<0,05$

\section{Factors influencing Character Strength of School Aged Children in Rural Families}

The table below shows the test results of influence between child characteristics, family characteristics, socialization method and peer attachment among character strength of school-age children. Age and peer attachment has a significant influence with the character strength of child. It means the increasing age has led to an increase achievement of character strength $(B=2,040 ; p=0,036)$ and then an increase of peer attachment led to an increase of child character achievement $(B=0,193 ; p=0,000)$. This model has a value of adjusted $\mathrm{R}$ Square of 0.171.It means that the model represents 
17,1 percent of the factors that affect the character strength of child and the remaining 82,9 percent influenced by other factors which was not examined.

Table 5 Regression analysis of child characteristic, family characteristic, socialization method, and peer attachment on character strength of school aged child

\begin{tabular}{lccc}
\hline \multirow{2}{*}{ Variable } & \multicolumn{2}{c}{ Character Strength } & \multirow{2}{*}{ Sig. } \\
\cline { 2 - 3 } Constant & 48,225 & Std. Error & 0,000 \\
Age (year) & 2,040 & 12,622 & $0,036^{*}$ \\
Sex (0=female, 1=male) & $-2,333$ & 0,959 & 0,136 \\
Age of father (year) & 0,248 & 1,550 & 0,129 \\
Age of mather (year) & $-0,263$ & 0,162 & 0,145 \\
Length of study of father (year) & 0,301 & 0,179 & 0,316 \\
Length of study of mother(year) & 0,674 & 0,298 & 0,073 \\
Income per capita (IDR/month) & $2,845 \mathrm{E}-7$ & 0,371 & 0,862 \\
Family size (person) & $-0,170$ & 0,000 & 0,764 \\
Socialization method & 0,026 & 0,564 & 0,706 \\
Peer attachment & 0,193 & 0,068 & $0,000^{* *}$ \\
\hline F & \multicolumn{3}{c}{0,049} \\
\hline Sig. & \multicolumn{3}{c}{3,043} \\
\hline Adjusted $R$ Square & 0,002 & \\
\hline$R^{2}$ & 0,171 \\
\hline
\end{tabular}

(**) significant at $p<0,01 ;(*)$ significant at $p<0,05$

\section{Discussion}

Childhood (late childhood) lasted for six years until individual become sexually mature (Hurlock 1980). The age of children in this study was upscale aged children of primary school. The results showed that half $(50 \%)$ of the children in this study attain the age of 11 years old. The end of childhood is considered as a period when the child is more influenced by his friends than the mother or other family members. Therefore, it is imperative to equip school-age children with character strength that eventually the child can adapt and survive in its environment.

The character strength of school-age children in rural areas, Pamijahan SubDistrict, Bogor Regency is categorized high. It can be seen from the achievements of the average and the highest proportion of each dimension of the high character strength. This study is in line with the research of Park, Peterson, and Seligman (2004) which states that the higher the value was, the more powerful the character was. However, it is not in line with the research of Dewanggi (2014) which showed that the character of children in urban areas is higher than the character of children in rural areas. Among the six dimensions of character strength, the highest achievement of average was a transcendence character that is the character strength that is characterized by assuming that worship is important to do so it is important to be diligent in worship and always be grateful for everything that is obtained. In contrast to the research of Seligman et al. (2007) conducted in the United Kingdom which showed that the dimensions of the highest character strengthis a character with the characteristics of an open outlook, justice, courage, and is being studied. In this study, the character strength was more significantly affected by stickiness peer attachment. 
The result of the relationship indicates that the child characteristics and family characteristics, as well as the length of study of father were related to the character of courage and transcendence. The length of study of mother relates to the character of courage and peer attachment which significantly have positive association with all dimensions of character strength such as courage, humanity, justice, temperance, and transcendence except wisdom.

Character strength was first formed by the family. One of the way is by the implementing of socialization method. The study of Hastuti, Alfiasari, and Sarwoprasodjo (2013) shows that the family environment which has high democratic parenting style and implement diverse methods of dissemination having significant influence with the character strength of the child. The research looked at the effect of the method also the effect of socialization by the mother to the character strength of school-age children in rural families. There are six socialization methods such as method of affective, cognitive, operant, observation, appreticenchip, and socioculture (Berns, 1997). The results showed that socialization method of socioculture has the highest average of achievement. But on the whole of the sixth dimension, more than half of rural families are at a low level of socialization methods. Unlike this study, Marliani's study (2014) showed that the category of socialization method done by mother in situ Gede area. It can be seen also in terms of family income and low education. Previous research conducted by Berns (1997) shows that family income is positively related to socialization method. When the family income is low, the implementation of socialization method was also low. This research showed that the income has positive relation with socialization method too. If income of rural families are low, it will be related to the implementation of dissemination socialization method which is low and not optimal. As it can not be generalized entire rural families that if have a low income then socialization method of rural families are low. According to Handel, Cahill, and Elkin in Berns (2013), the socialization method can occur in various social groups either low or high.

Peer attachment seen from how close children with peer group. Santrock (2007) emphasized that the close relationship built on friendship, the higher its influence to the children. The relationship that have been built for a long time eventually will build emotional bond with each other. This is called as attachment. Bowlby (1992) defines attachment as an emotional relationship between one individual with another individual that has a special meaning. According to Armsden and Greenberg (1987), attachment with peers occurs when a friendship has existed a long time and the friendship has been built up through trust, communication, and acceptance conducted by the adhesion. In the variable of peer attachment, dimension of communication becomes one thing that make the attachment possibly happens. Susanti (2013) states that communication is one of the factors that influence attachment with the peer group. When the child is able to communicate well so the trust with friends can be maintained. If in the relationship there are trust, comfort feeling, and closeness, attachment will be formed (Armsden \& Greenberg, 2009).

The results showed that the three dimensions of peer attachment: trust, communication, and acceptance were in middle category. Armsden and Greenberg (1987) classified the attachment into high security and low security. The results showed 
a lack of compatibility with atheory developed by Armsden and Greenberg (1987) where the dimensions of trust and communication was in middle category. It means that attachment with peers are in the safe category. From the test results showed the relationship between the child's age and maternal age which showed a significant positive correlation with the dimensions of acceptance. The maturity of child age will increase the attachment with peers. These results are consistent with research of Gullone (2005) stating that the attachment will be more closely at the age when school children are growing especially when the child enters adolescence. In addition, the length of education of father significantly and positively associated with children's communication. This shows that the longer and the higher the father's education or the father's education level,the better communication built by a child with his friends. This is consistent with research of Armsden (1986) which states that attachment with peers significantly and positively associated with parental education. The results showed the peer attachment significantly and positively affect on the character strength of the child.

Results of this study did not find an association or significant influence of socialization methods by the mother to character strength of school-age children in rural families in regression models constructed. The study found that only peer attachment influence character strength of school-age children in rural families. It is shown by the relationship and the significant influence of peer attachment with character strength of school-age children in rural families. It can beseen from the value of adjusted $\mathrm{R}$ square regression model that is 0,171 .It means that from the independent variables studied only 17,1 percent that affect the character strength of children and 82,9 percent are influenced by other variables not examined in this study. When a socialization method becomes the independent variable in this study, it did not have a significant influence on the character strength of school-age children in the family of rural areas. It means that there are other variables which belongs to the family as an agent of socialization that may affect significantly as parenting style (Alfiasari, Hastuti, \& Sarwoprasodjo, 2013), maternal attachment (Marliani, 2014), as well as life satisfaction and well-being (Park, 2009). Therefore, research about character strength must be continued to know which variable gives greater influence on the character strength of school-age children in rural families.

\section{Conclusion and Suggestion}

\section{Conclusion}

The result test of the relationship showed that from the child and family characteristics, only income per capita has significantly and positively associated with the socialization method. The variables of relationship between the child and family characteristics to peer attachment which was significantly positive are the age of child, age of mother, length of study of father, and family size.Then, from testing the relationship between the child and family characteristics, the variables of socialization methods and peer attachment which was positively and significantly related are the length of study of father and mother and peer attachment. Further, from results of multiple linear regression of the independent variables studied, only the age of the child 
and peer attachmentthat give significantly positive effect to the character strength of school-age children in rural families.

\section{Suggestion}

This study shows that the father and mother's education is still low, with an average length of education that is up to primary school level. Lack of education will have an impact on the level of income. The government needs to improve the quality of education in Indonesia. The results also show that the method of socialization by the farmer family has not been done optimally. The government should be able to carry out the process of educating and increasing awareness and concern to the community in the implementation of the socialization method of children by conducting counseling and through seminars. Additionally, if you see the results of studies showing that the peer attachment gives more influence on a child, it is expected that the need for synergy between the family and the school in the form of friendship environment is conducive to the formation of character to become more optimal. Furthermore, to be able to explain in a comprehensive picture of the character of school-age children in rural families, hoping to conduct further research on character strength by using variables other than the method of socialization and attachment to peers. Additionally, the researchers want to examine the relevant methods of socialization, it is expected the additional cases in some of the statements in the instrument method of socialization. Then in order to get accurate measurement results, in addition to using a structured questionnaire it is necessary to direct observation.

\section{Reference}

Armsden, G. C., \& Greenberg, M. T. (1987). The inventory of parent and peer attachment: relationship to well-being in adolescence. Journal of Youth and Adolescence. 16, 427-454. doi: 10.1007/BF02202939.

Armsden, G. C., \& Greenberg, M. T. (2009). Inventory of parent and peer attachment (IPPA). Journal Health and Human Development.

Berns, R. M. (1997). Child, Family, School, Community: Socialization and Support. US: Harcourt Brace College Publishers.

Bowlby, J. (1992). The origins of attachment theory: John Bowlby and Mary Ainsworth. Developmental Psychology. 759-775

Dewanggi, M. (2013). The influence of attachment, parenting style, and environmental quality of care to the character of rural and urban children (Master's thesis).Retrived from http://repository.ipb.ac.id/handle/123456789/71911,

Gullon. (2005). The inventory of parent and peer attachment revices (IPPA-R) for chilldren: a psychometric investigation. Journal of Psychology and psychotherapy. 12, 67-79. doi: 10.1002/cpp.433. 
Hastuti, D., Sarwoprasodjo, S., \& Alfiasari. (2013). Integration of family relationships and the school's strength of character and prosocial behavior of teenagers in Bogor Indonesia. [Papers]. Bogor (ID): Bogor Agricultural University

Hurlock, E. B. (1980). Psychology Child Development: An Approach Throughout Range Life (5th ed.) (Istiwidayanti, Soedjarwo, Trans.; Silabat, R, M, Eds.). Jakarta, Indonesia: Erlangga.

Lickona, T. (1994). Raising Good Children: From Birth through the Teenage years. New York, NY: Bantam.

Marliani, Y. F. (2014). Effect of maternal attachment method of socialization and the teenage characters in the Village of Situ Gede Bogor City. (Undergraduate thesis). Retrived from http://repository.ipb.ac.id/handle/123456789/72234.

Nadiya, A. 2013. The relationship between the welfare of the family and child welfare on farm families (Undergraduate thesis). Retrived from http://repository.ipb.ac.id/handle/123456789/67379.

Naibaho, F. D. (2013). Maternal parenting style, attachment with peers, and adolescent self-concept in the family (Undergraduate thesis). Retrived from http://repository.ipb.ac.id/handle/123456789/66289.

Litman-Ovadia, H., \& Davidovitch, N. (2010). Effects of Congruence and CharacterStrength Deployment on Work Adjustment and Well-Being. International Journal of Business and Social Science. 1(3), 137-145. Retrived from http://ijbssnet.com/journals/Vol._1_No._3_December_2010/14.pdf.

Park, Peterson, \& Seligmen. (2004). Strengths of character and well-being. Journal of Social and Clinical Psychology, 23(5), 603-619. Doi: doi: 10.1521/jscp.23.5.603.50748.

Pasaribu, R. M. (2013). The influence of parenting styles and methods of dissemination of parents of honest character and responsibilities of high school students in the city of Bogor (Master's thesis). Retrived from http://repository.ipb.ac.id/handle/123456789/62105.

Santrock, J. W. (2007). Child Development (11th ed.). Jakarta, Indonesia: Erland.

Seligman, et al. (2007). Character strength in the United Kingdom: The VIA Inventory of Strengths. Personality and Individual Difference. 341-351. Doi: doi: 10.1016 / j.paid.2006.12.004.

Statistics Indonesia. (2013). West Java in 2013. Figures Jawa Barat, Indonesia: Author.

Susanti. (2013). Communication and attachment to parents, attachment to peers, as well as life satisfaction teenage mothers by working status (Undergraduate thesis). Retrived from http://repository.ipb.ac.id/handle/123456789/66069. 